\title{
Hydropower and Tourism in Iceland: Visitor and Operator perspectives on preferred use of natural areas.
}

Authors: Georgette Leah Burns ${ }^{1,2}$ and Laufey Haraldsdóttir ${ }^{2}$

${ }^{1}$ School of Environment and Science, and Environmental Futures Research Institute, Griffith University, Nathan 4111, Queensland, Australia

${ }^{2}$ Department of Rural Tourism, Hólar University College, Iceland

\section{Corresponding authors:}

Georgette Leah Burns. School of Environment and Science, and Environmental Futures Research Institute, Griffith University, Nathan 4111, Queensland, Australia.

leah.burns@griffith.edu.au

Laufey Haraldsdóttir. Department of Rural Tourism, Hólar University College, Iceland. laufey@holar.is

\begin{abstract}
:
This paper examines visitor and tourism operator perspectives of a recreation destination in the face of competing land use from the potential industrial development of a hydroelectric power plant. Questionnaires and interviews were employed to discover (i) how and why the area is used for recreational activities by both Icelanders and foreigners, (ii) the satisfaction of two key stakeholder groups: visitors to the area and local tourism business operators and, (iii) the opinions held by these groups with regards to the potential impacts of the proposed development on tourism and recreation in the region.

Analysis of the questionnaire data revealed that the majority of visitors were extremely satisfied with their experience of nature in the area and, correspondingly, that construction of hydropower facilities would deter them from visiting. Opinions of interviewed operators were more varied, based on their type of business and distance from the proposed development site. Some welcomed potential improved access to the areas, but most held concerns that the development of hydroelectricity could negatively affect the natural environment, and the visitor experience, resulting in negative impacts on tourism in the area.

These data were incorporated into a report prepared for the Icelandic government to assist their decision making in how best to manage this natural area in the future. The proposal for hydropower in the region was rejected and the area recommended for special protection status under Icelandic legislation.
\end{abstract}

Keywords:

Iceland, tourism, hydroelectricity, land use, satisfaction, stakeholder.

A statement or list of management implications (150 words or less)

From this research we learnt that visitors to natural areas value a perception of wilderness, sharing the opinion that the introduction of infrastructure for hydropower would detract from that value and thus negatively influence satisfaction with their experience of the area. Tourism operators are aware of this perception by visitors, and the strong drawcard of an area that is perceived to be undeveloped.

For similar planning processes, both within Iceland and other countries, we recommend that: 
- longitudinal monitoring of visitor and operator (host) satisfaction is undertaken to determine the potential effects of the introduction of hydropower infrastructure on recreational experience,

- visitors are included as stakeholders in decision making about the development of natural areas, and

- the opinions of all stakeholders are sought and considered when making decisions about land use options.

\section{Introduction}

The search for an appropriate, efficient and sustainable, source of electricity generation has long been a challenge in Iceland. In a country of just over 330000 people, on the edge of the Arctic circle, overwhelmed by tourism and recovering from severe financial crisis, addressing this challenge is critical. Concurrently, Iceland's dependence on utilization of its natural resources for economic welfare "presents a major challenge for the nation" to use these resources sustainably (Sæpórsdóttir \& Ólafsdóttir, 2017, p.5) and to balance the competing demands for them.

In 1999, the Icelandic government commenced a project, led by the Ministry of Industry, Energy and Tourism in co-operation with the Ministry for the Environment, entitled The Master Plan for Geothermal and Hydropower Development. Phase 1 of the project ran from 1999 to 2003 and phase 2 from 2004 to 2010 (Sæpórsdóttir \& Ólafsson, 2010, p.334). The project was subsequently renamed The Master Plan for Nature Protection and Energy Utilization and in its third phase, during which this project was conducted, The National Energy Authority (Orkustofnun) introduced 83 options for generating power in Iceland. The steering committee for the Master Plan prioritized evaluation and ranking of 26 options. Two of these options utilised wind turbine technology and the remaining 24 were either hydroelectric or geothermal power plants (Gíslason, 2016). Funding was made available by the government to assess the viability of these options. The study described here is part of that larger, nationwide, project conducted at numerous locations across Iceland by several research groups, each evaluating the effect of different power generation options on tourism and recreation.

Tourism and power generation have grown rapidly in Iceland over the last few decades (Sæpórsdóttir \& Saarinen, 2015) and both are now critical to the Icelandic economy (Sæpórsdóttir et al., 2018). As Iceland increasingly engages with power intensive industries, such as alumina smelters, the demand for electricity grows. International visitor numbers are also rapidly increasing in Iceland (Óladóttir, 2017) and the natural features exploited for power generation are also often the very same features these visitors come to see. In addition, the value of natural places as sites for recreation for Icelanders is also important. Despite this, baseline data for ongoing monitoring of tourism and its impacts on the environment is lacking for many destinations in Iceland. This lack of data is at least in part a consequence of the infancy of foreign tourism, and associated research, in the country.

During the research described in this paper, three proposals for hydroelectricity development, at two locations in Skagafjörður (Villinganes and Skatastaðir), were under consideration in the third phase of the Master Plan. Concurrently, the tourism sector in Skagafjörður was developing rapidly and the value of tourism in the region was high (Sæpórsdóttir \& Ólafsson 2010). 
The region is popular for different types of recreational activities; including rafting, horse riding, and hiking. The Icelandic Tourist Board reports an approximately $39 \%$ annual increase in number of foreign visitors entering the country over the last five years (Óladóttir, 2017), and overnight stays in Skagafjörður increased by $24.5 \%$ between 2016 and 2017 (Pálsson, 2017). As further evidence of this growth, 41 tourism businesses were registered in Skagafjörður in 2012 (Ferðamálastofa, 2012) and by 2015 this had more than doubled to 99 (Arinbjarnarson, 2016). In addition, all of the tourism operators interviewed in this study expressed a certainty of increased number of visitors both at their business and to the area.

The proposal to introduce a hydroelectric power plant and associated facilities (herein referred to as 'hydropower') in Skagafjörður potentially effects many different stakeholders, because of the existing and potential land use in the area. The region is already home to sheep and horse farmers and has become a destination for tourism. As different stakeholder groups are likely to differ in their opinions over how a destinations' resources should be utilized (Moisey \& McCool, 2001), we focused on two stakeholder groups in this research: visitors to the area and local tourism business operators. The aim of the research was to understand the potential impacts of the three power plants on tourism and recreation in the region. To facilitate this, we investigated (i) what tourism and recreational activities exist in the area; who uses the area for recreation and why, (ii) the satisfaction of visitors and local tourism business operators with the region, and (iii) the opinions of both these stakeholder groups concerning potential impacts of the power plant proposals.

\section{Literature Review and theoretical framework}

The many possible stakeholders in natural area tourism are identified in numerous models (e.g., Newsome et al., 2002). These include, but are not limited to, tourism businesses operating in the natural area (e.g., Haukeland 2011), members of local communities, managing government authorities, and the visitors themselves. The groups are not mutually exclusive; a member of the local community, for example, may operate a tourism business and also use the region for their own recreation. Of particular interest in this study are the visitors choosing the area as a recreational destination, both Icelanders and visitors from outside the country, as well as local tourism business owners and operators. These groups of people may have contrasting views on appropriate development in the region, and different levels of satisfaction with existing facilities and the experience offered.

\subsection{Stakeholder opinions of land use options}

How a destination's resources should be utilized is likely to be viewed differently by different stakeholder groups (Moisey \& McCool, 2001; Plieninger et al., 2018). An example of this in Iceland in the context of hydropower are the disputes around Fljótsdalsvirkjun and later Kárahnjúkavirkjun, on the east side of the country, with the latter becoming the biggest hydropower operation ever in Iceland's history (Ólafsson, 2006). The dispute lasted almost twenty years, with the Icelandic government and Landsvirkjun (the National Power Company of Iceland) as well as local authorities in favor of the development of hydropower. Meanwhile, other stakeholders, such as The Icelandic Environment Association, local nature conservation associations and local tourism associations, along with several public figures in Iceland, were against the development. The general public around the country were divided between those in in support of, and those against, the hydropower. The involvement of 
international preservationists in mass demonstrations connected to these disputes shows that environment and nature conservation, in all parts of the world, has become an important element in the lives of individuals in modern society (Karlsdóttir, 2010) and thus demands consideration in planning and management.

Visitors to natural areas tend to hold a more positive view of landscapes that have not been recently changed by human activities (Frantál \& Kunc, 2011), although this partly depends on the nature of such changes. On the other hand, local residents may perceive more positively the potential to use a natural landscape as a resource and thereby change it, to satisfy a need for electricity for example, than non-local visitors to the region. Meeting the differing demands of all stakeholders may not be possible; thus, the challenge for natural area managers lies in reaching consensus in the face of these differences and balancing the needs of all stakeholders (Sæpórsdóttir \& Ólafsdóttir, 2017).

\subsubsection{International examples}

Literature that explores tourism and hydroelectric power generation as competing, or complementary, land use activities is minimal, despite these types of land use requiring similar types of environments. The water flow and storage potential necessary for effective power generation relies on natural features, such as fast flowing rivers in often remote and mountainous locations, and such features are also favoured by nature-based tourists. These environments occur widely around the world in countries such as Australia, Europe, Canada, America and Iceland.

In Australia, the Gordon Power Station offers an example of a very controversial project that galvanised significant national support for natural area conservation when the dam was first proposed (Pybus \& Flanagan, 1990). At this time, the key stakeholders were the Tasmanian government and environmentalists. Lake Pedder, flooded in 1972 to create the reservoir necessary for hydropower, has become an icon for Australian nature conservation (Kiernan, 2017) and debate persists over its restoration (Schweinsberg et al., 2015). The area is now visited by recreationists who kayak and raft on the river, hikers, and some visitors who come specifically to see the historic site, though numbers are few, due to the remote and fairly inaccessible location. The former Lake had potential as a destination for nature-based tourists but how significant that may have become remains unknown. The development of hydropower in this location could be argued to have contributed to increased visitor numbers over time and thus added visitors as a current stakeholder in this region.

Rodriguez (2012) researched landscapes in the Pyrenees mountain range where hydropower development and associated infrastructure is an "omnipresent" (p.1), "clearly visible ... [and] symbolic object" (p.3). Hydropower and visitors co-exist in this location, with the infrastructure becoming part of the tourist attracting landscape, similar to Tasmania. This apparently satisfactory co-existence may, in part, be due to the longevity of this type of development in the region and thus visitor expectation and acceptance of it. This can also be seen in east Canada, for example, where the Mactaquac hydroelectric generation station has existed since the 1960 s alongside recreation and subsistence use of the rivers and the region by First Nations peoples (Energy NB Power, 2016).

In many cases, the facilities implemented primarily for construction and maintenance of hydropower are adopted for tourism use over time, and once the life of the hydropower is over this can leave economic and social gaps for the local community. For example, decommissioning of the Cushman Hydroelectric project constructed in the US state of 
Washington in the 1920s caused concern for local businesses dependent on tourism generated from activities on the lakes formed by that project (Federal Energy Regulatory Commission, 1996).

Decommissioned power stations are a tourist attraction in some countries. The Waddamana Power Station in Tasmania, for example, was converted into a museum in 1988 displaying restored original hydro-electric machinery and historical photographs, and several other Stations in Tasmania have since copied this model (Hydro-Electric Corporation 2017). These international examples suggest some acceptance by visitors of existing hydropower infrastructure, but objection to new construction, particularly in areas where it does not already exist. A similar situation is apparent in Iceland.

\subsubsection{The Icelandic context}

In Iceland, the first hydropower station commenced operation in the town of Hafnarfjörður, near the capital of Reykjavik, in 1904 and hydropower now generates nearly 80\% of the electricity in the country (Askja Energy, 2017). Most hydropower stations, however, are in more remote areas, such as Blönduvirkjun (the Blanda power station) on the north western edge of the highlands in Blöndudalur (the Blönduos Valley), Búrfellsvirkjun in the south west edge of the highlands in Pjórsárdalur, and Kárahnjúkavirkjun on the east side in Fljótsdalur.

In a recent study of the influence of hydropower on visitor experiences in Iceland, Sæbórsdóttir and Hall (2018) compared opinions of visitors in the region of the existing Blanda power station with those of visitors in other areas where hydropower facilities do not yet exist but have been proposed. Their results showed that the visitors at Blanda, which commenced operation in 1991, were more positive towards power plants than visitors at locations of proposed power plants. This agrees with findings described above in the international context, namely that stakeholders were often initially negative about power plant proposals but accepting of them once they had been implemented.

Nevertheless, the issue of potentially contesting land use between tourism and hydropower options arises as visitation to remote areas increases, as is currently happening in Iceland. Varying stakeholder opinions of appropriate land use options may be linked to satisfaction with their experience in the area, which is why we explored satisfaction amongst both visitors and operators.

\subsection{Satisfaction}

In tourism discourse, satisfaction is widely accepted to refer to the emotional state of a visitor after experiencing a destination (Rodger et al., 2012; Moore et al.,2015), and is frequently cited as a measure of the quality of a visitor's experience. Moore et al. (2015, p.669), caution that satisfaction and service quality have a lengthy history of overlap and confusion; however, in the tourism and recreational literature the two terms are usually treated distinctly, with satisfaction considered in more general terms and regarded as more subjective. Nevertheless, satisfaction is used by managers to understand the types of experience visitors seek and thus how to provide services and facilities to match these expectations (Hornback \& Eagles, 1999; Tonge \& Moore, 2007).

Matching expectations, and thus achieving satisfied visitors, is important for the long-term success of any tourism attraction (Alegre \& Garau, 2010). In the context of park tourism, visitor satisfaction is one of ten priority issues identified by Eagles (2014) as critically important to effective park management, and is based on appropriate levels of 
environmental quality as well as suitable levels of customer service (Eagles, 2002). For these reasons, research into visitor experiences in parks and natural areas has become an integral part of understanding how visitors value these locations and has increased in importance as a management tool (Pearce \& Dowling, 2018).

Satisfaction has been, and remains, "a centrepiece of visitor research in nature-based tourism" (Moore et al. 2015, p.668). It is usually measured by perceived performance against a series of attributes, such staff friendliness (Newsome et al., 2013), signs and restrooms (Tonge \& Moore, 2007). It is also usually focussed solely on one stakeholder group: the visitors.

As identified earlier, visitors are one of many stakeholders in natural areas. While understanding their satisfaction is important for effective management, so too is knowledge of the satisfaction levels of other stakeholders in terms of destination sustainability. Thus, understanding the satisfaction of the local tourism business operators, who rely on natural areas for their livelihood, is also valuable. This is an often-neglected topic of discussion in the tourism literature.

When satisfaction is discussed in connection with tourism operators, the focus is usually on how the operator can assist the visitor to be more satisfied (e.g., Williams \& Soutar, 2007) rather than on the satisfaction of the operator themselves. This literature covers topics such as the importance of operator competencies (Mohamad et al., 2017) and ways to address service quality, as discussed above. Consequently, the present study offers a contribution to this neglected area in the literature about operator satisfaction.

\section{Methods and Analysis}

This research was funded by the Icelandic Ministry for the Environment and Natural Resources and conducted by researchers from the Department of Rural Tourism at Hólar University College as part of a nationwide project managed by the University of Iceland. For this part of that project, focusing on hydropower in Skagafjörður, data were collected during the second half of 2015 through questionnaires with visitors and interviews with tour operators. This mixed method approach gathered both quantitative and qualitative data to provide information about the status of tourism in the potentially affected area and those factors attracting visitors to the region. Importantly, it also enabled us to explore how both visitors and operators perceive the area and its value for tourism, and satisfaction with their experiences in the region.

\subsection{The study location}

Skagafjarđardalir encompasses two parallel glacial river valleys, Austurdalur and Vesturdalur, in the southernmost part of Skagafjörđur. The East and West glacial rivers (Austari Jökulsá and Vestari Jökulsá) run through the valleys from the highland north of Vatnajökull National Park, before combining to continue travel through the populated region of Skagafjördur and into the Atlantic Ocean. Austurdalur (the easterly valley), is largely uninhabited with limited access, while Vesturdalur (the westerly valley), contains a gravel road used as a gateway from Skagafjörđur to the central highland region of Iceland.

For over forty years the potential for the generation of hydroelectric power from the East and West glacial rivers has been investigated (Morgunblaðið, 1975). The earliest proposal 
included construction of a power plant at Villinganes, north of where the East and West glacial rivers converge (Morgunblađið, 1975). The potential impacts of this plant on tourism in the area were reported by Rögnvaldsson in 2000.

During the research discussed here, three proposals for hydroelectric power plants, in the area where the valleys and their corresponding glacial rivers are located, were under consideration in the third phase of the Master Plan (see Map One):

1. Villinganes Power Plant (R3108A Villinganesvirkjun)

2. Skatastaðir Power Plant C (R3107C Skatastaðavirkjun C)

3. Skatastađir Power Plant D (Villinganes + Plant C) (R3107D Skatastađavirkjun D)

The first proposal suggests a power station at Villinganes, similar to the original proposal in the 1970s. The second proposes a power station in Skatastadir, located further south in Austurdalur, and the third suggests the construction of power stations at both locations. Any three of the proposals includes the creation of a large reservoir near Hofsjökull glacier.

Map One: Location of the proposed power plants and associated infrastructure in Skagafjörđur (reproduction permission from Anna Dóra Sæpórsdóttir).

\subsection{The questionnaire}

Visitors were surveyed during the month of July 2015 at locations near the proposed hydropower plant sites and also at local tourism businesses. Many of these locations were places travelers returned to after taking part in activities in the region including rafting, horse riding, hiking and angling trips. July was chosen because it is one of the peak summer months for travel to, and within, Iceland.

The questionnaire contained 26 questions and was available for completion in four languages: English, Icelandic, French and German. It was paper based, one page double sided, and distributed and collected by hand. The researchers explained the purpose of the study to the respondents. This included showing respondents a map of the area (see Map One), with either English or Icelandic text, and explaining details of the three power plant proposals. The researchers stayed with the respondents while the questionnaire was completed, answered any questions raised, and collected the completed survey immediately afterwards.

Purposive sampling targeted visitors who had been into the areas likely to be affected by the power plants, such as those on three-day rafting tours or long horse riding tours. Consequently, most of the respondents (approximately 80\%) had visited Austurdalur or other locations close to the proposed hydropower sites. For those who had not, such as those surveyed at a hotel in Varmahlið (a small village north of the main research area), their opinions were based on information provided by the researchers about the power plant projects and not on any firsthand experience of the areas which would be affected. This does not diminish the validity of the responses because knowing opinions of these visitors, and whether the power plants would influence their decision to visit the wider area, was also relevant to the study. 
Questions covered visitor characteristics (gender, age, nationality, occupation), visit characteristics (type of activity, length of time in the area, number of times visited), satisfaction with and importance of environmental features, and attitudes toward development in the area. A few questions were open-ended, giving respondents opportunity to answer in their own words; however, the majority of the questions were multiple-choice closed-ended questions. For example, for questions related to both importance and attitudes, respondents were given a list of attributes and asked to assign a value to each using a unidirectional five-point Likert scale ranging from "not at all important" to "very important".

The survey was designed this way to assess attributes that determine satisfaction with visitor experiences in the areas. Visitors were asked how important each particular attribute was to them, following similar methodological approaches by Tonge and Moore (2007) and Wade and Eagles (2003). Multiple-item scales were used because they are considered a more valid measure of overall satisfaction (Lee et al. 2004). In addition, because matching expectations is directly linked with achieving satisfaction (Alegre \& Garau 2010), questions about expectations were also asked. Results were compiled using version 22 of the IBM Statistical Package for the Social Sciences (SPSS).

\subsection{The Interviews}

Interviews with 20 tourism operators were conducted between July and November 2015. Interviewees were purposefully chosen, and snowball sampling was also employed. Each operator interviewed was asked for suggestions of who else might be interviewed for this research. The 20 operators interviewed included those with businesses closest to the proposed power plant sites, those expected to be most affected (such as rafting, hiking and horse tour operators) as well as other prominent businesses in the Skagafjördur region. Fourteen of the 20 tourism operators run their businesses, or organize tours near the rivers or the proposed sites. Of the remaining six operators, three run their businesses a short distance north of Varmahlíð and three are based further north in Skagafjörður.

An interview guideline, containing key questions, was designed before the interviewing commenced. It was used to ensure all interviewees were asked about the same issues. For each interview, the interviewer travelled to the business of the tourism operator at a day and time convenient to them. The interviewees signed a letter of consent before the interview took place. The interviews were recorded, either on a mobile phone or on a portable audio recorder, and subsequently transcribed.

Five of the interviews were conducted in English, one was conducted in both English and Icelandic and the remaining 14 were conducted in Icelandic. The interview texts were transcribed in the language in which they were recorded and the Icelandic texts were then translated into English for the purpose of comparative analysis.

Content analysis of the qualitative interview data was conducted through semantic mapping to identify central themes embedded within each narrative. This analysis systematically assigns interview content to identify defining themes. Through identifying and synthesizing broad themes, we provide an empirical basis for identifying the perceptions and values of the interviewees (Kvale \& Brinkmann, 2009). Concepts emerged through an analysis of frequency, and the comparison of phrases and words with similar usage. Identified concepts were depicted as themes on semantic maps, and the analysis results display the 
interconnectedness and co-occurrence of concepts and provided the basis for semantic descriptions (Neuendorf, 2017).

\section{Results}

This section presents findings from the questionnaires and interviews. A visitor profile constructed from the data precedes comments on visitor satisfaction and perceptions of the area, as well as their attitudes towards hydropower and preferences for management of the region. This is followed by a profile of the businesses, their activities and the number and type of visitors they attract. Operator perceptions of the region, and their attitudes towards hydropower and preferences for regional management are then presented.

\subsection{Questionnaire Data: visitor profile and perspectives}

A total of 223 valid questionnaire responses were collected. The largest number was gathered from visitors at rafting (31\%) and horse riding (24\%) businesses. Guests at accommodation facilities (20\% of all respondents) and hiking in the area (8\%) were also surveyed. English was the most common language chosen to fill out the questionnaire (44.8\%), followed by German (31.4\%), Icelandic (19.3\%) and French (4.5\%) (Table 1).

Table 1: Origin of questionnaire data (Burns \& Haraldsdóttir 2016). Showing location (business type) where the questionnaire was completed and the language chosen by visitors when completing the questionnaire.

\begin{tabular}{|l|c|c|c|c|c|}
\hline \multirow{2}{*}{ Location } & \multicolumn{5}{|c|}{ Language } \\
\cline { 2 - 6 } & English & German & Icelandic & French & Total \\
\hline Rafting business & 48 & 12 & 6 & 4 & 70 \\
\hline Horse riding businesses & 16 & 37 & 0 & 0 & 53 \\
\hline $\begin{array}{l}\text { Accommodation } \\
\text { (Hotel/Guesthouse/Camp ground) }\end{array}$ & 12 & 20 & 12 & 1 & 45 \\
\hline $\begin{array}{l}\text { Mixed tourism business (includes } \\
\text { accommodation, rafting, angling } \\
\text { but not horse riding) }\end{array}$ & 24 & 1 & 6 & 5 & 36 \\
\hline Hikers hut in Austurdalur & 0 & 0 & 17 & 0 & 17 \\
\hline Petrol Station/Store & 0 & 0 & 2 & 0 & 2 \\
\hline Total & 100 & 70 & 43 & 10 & 223 \\
\hline
\end{tabular}

\subsubsection{Visitor profile}

Of the 223 questionnaire respondents, $58 \%$ identified as female and $42 \%$ as male. The slightly higher percentage of females may be attributed to horse riding being a major 
attraction in the area, and the majority of travelers to Iceland who participate in horse riding are female.

The age of respondents ranged from 14 to 81 . Respondents were most frequently between $25-40$ years of age (33\%), followed by over 55 (27\%) and $41-55$ (23\%). The average age was 42 , with a standard deviation of 17.

Just over half the respondents (54\%) originated from Europe. Origin of the other $48 \%$ was divided amongst Iceland (18\%), other Nordic countries (12\%), North America (11\%) and the rest of the world (5\%).

Most of the respondents (73\%) were travelling with family members $(35 \%)$ or friends $(38 \%)$, while $17 \%$ were part of an organised tour and just $6 \%$ were traveling alone or with colleagues (3\%). Popular activities included rafting (52\%), walking (51\%), and horse riding (49\%), which were also all noted as activities that particularly attracted respondents to the area.

Of the $54 \%$ of respondents travelling by car, $22 \%$ were in private cars (therefore likely to be Icelandic) and $32 \%$ in rental cars (therefore likely to originate from another country).

Twenty one percent were travelling by bus, either by coach in an organized group or by the national bus company. Some of the visitors were on horse riding tours $(16 \%)$ or hiking $(8 \%)$ in the area at the time they completed the questionnaires.

Visitors staying in the area for just a few hours and up to one day (25\%), two to four days (34\%) and five to seven days (30\%) were fairly evenly distributed in the results. The percentage reduced considerably at eight to 14 days (8\%) with only $3 \%$ staying longer than 14 days.

Most of the respondents (81\%) were first time visitors to the region. Of those who had visited before (19\%), the percentage was fairly evenly spread between those who had visited once before (33\%), those who had visited two to four times before $(21 \%)$ and those who had visited five to ten times (38\%). The percentage reduced considerably at ten or more previous visits (8\%). This followed a pattern noted by interviewed horse riding tour operators in particular, who reported multiple repeat visitation by their guests.

The most commonly represented occupation of respondents was professional (39\%), followed by students (15\%) and those in managerial (13\%), clerical or service (9\%) positions. Working at home (3\%) and unskilled (1\%) were the lowest represented occupations.

From the demographic data collected (Table 2) a profile of the 'average' visitor to the area shows they are most likely to be a professional, 42 year old female from Europe, on their first trip to the region, travelling in a rental car with friends or family, staying for 2-4 days, and taking part in rafting, horse riding or walking activities.

Table 2: Visitor Characteristics

\begin{tabular}{|l|l|l|}
\hline Category & Sub-category & $\begin{array}{l}\text { Percentage of Respondents } \\
(\mathbf{N}=\mathbf{2 2 3})\end{array}$ \\
\hline Gender & Female & 58 \\
& Male & 42 \\
\hline Age & Under 25 & 17 \\
& $25-49$ & 33 \\
& $41-55$ & 23
\end{tabular}




\begin{tabular}{|l|l|l|}
\hline & $56+$ & 27 \\
\hline Origin & Europe & 54 \\
& Iceland & 18 \\
& Other Nordic countries & 12 \\
& North America & 11 \\
& Rest of the World & 5 \\
\hline Travelling Companions & Family & 35 \\
& Friends & 38 \\
& Organised tour & 17 \\
& Travelling alone & 6 \\
\hline Mode of Travel & Private car & 22 \\
& Rental car & 32 \\
& Bus & 21 \\
& Horse back & 16 \\
& Hiking & 8 \\
\hline Length of Stay (days) & 1 or less & 24 \\
& 2-4 & 34 \\
& 5-7 & 30 \\
& 8-14 & 8 \\
& 15 or more & 3 \\
\hline Occupation & Professional & 39 \\
& Student & 15 \\
& Managerial & 13 \\
& Clerical or Service & 9 \\
& Home Duties & 3 \\
& Unskilled & 1 \\
\hline
\end{tabular}

\subsubsection{Visitor perceptions of, and satisfaction with, the area}

Expressing opinion on a five point Likert scale, most respondents agreed, or strongly agreed, that four words were highly favored for describing the area: natural $(97 \%)$, beautiful $(97 \%)$, quiet (96\%) and impressive (95\%) (Figure 1). When invited to describe in their own words what drew them to the area, visitors frequently chose words related to the natural state of the area: it being "untouched" and "undeveloped". Eighty nine percent of respondents agreed or strongly agreed that they chose destinations like this one so that they can rest and recover. The same number (89\%) agreed or strongly agreed that they choose destinations like this for reasons of escapism and to put their everyday worries aside, demonstrating a link between visitor perceptions of naturalness and relaxation. 


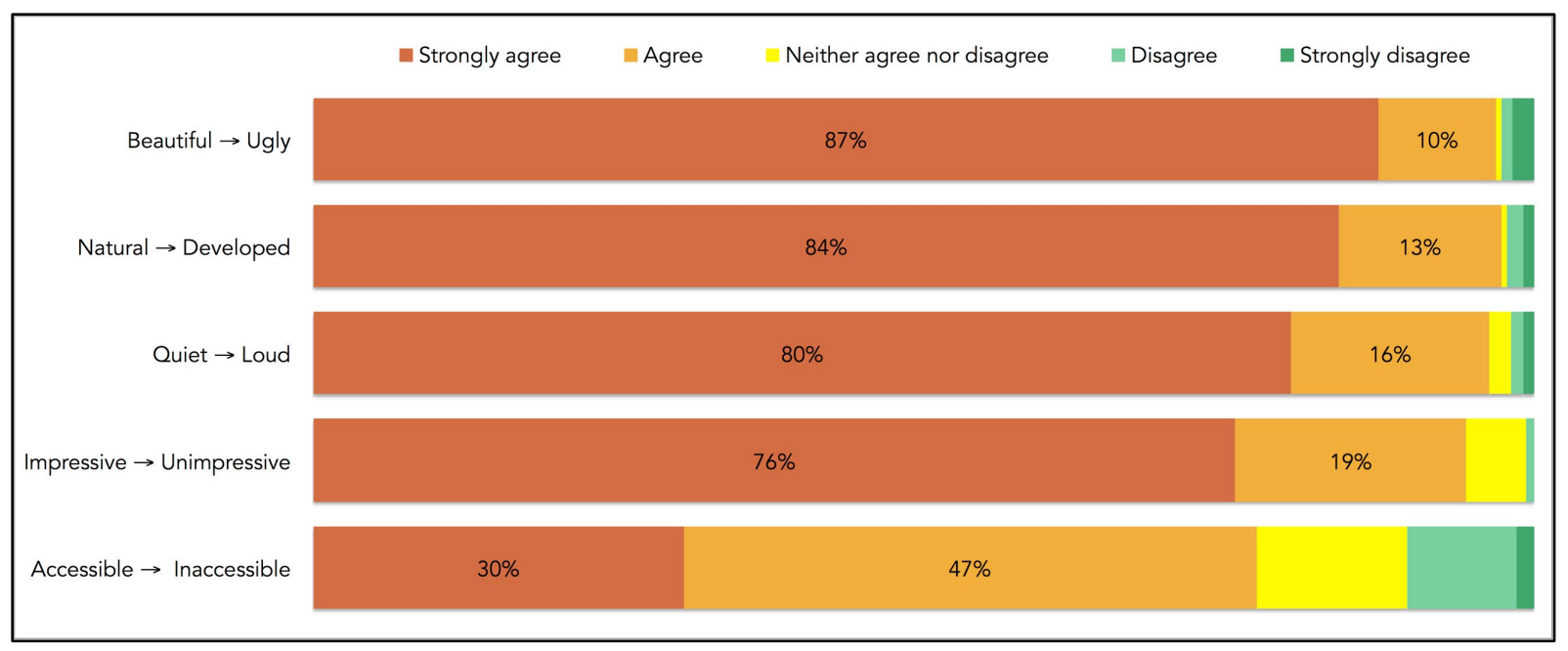

Figure 1: Visitor preferences for descriptions of Skagafjarðardalir and the surrounding area (Burns \& Haraldsdóttir, 2016).

The importance of wilderness, or unspoiled nature, was strongly identified. Only $1 \%$ of respondents thought that wilderness was not part of the attraction of the area. Five percent had no opinion and wilderness, or unspoiled nature, was a critical part of the attraction for $94 \%$. They ranked highly the importance of being able to "enjoy unspoiled nature" (97\%) and "enjoy peace" (91\%) as part of their experience in the area. Far less importance was placed on the provision of introduced facilities to the area such as picnic benches and tables (19\%), and designed footpaths (25\%). In total, $85 \%$ of respondents said they visited the area specifically to experience wilderness/unspoiled nature.

Overall, respondents reported extremely high levels of satisfaction with their experience of tourism in the area (Figure 2). Ninety two percent were satisfied, or very satisfied, with the nature in the area and $91 \%$ were satisfied, or very satisfied, with their stay in the area.

These results demonstrate a link between visitor satisfaction and perceptions of naturalness, which could lead visitors to feel dissatisfied if they perceive the nature to be compromised. As one visitor commented: "It [presence of hydropower] would be horrible, the unspoiled nature would be destroyed".

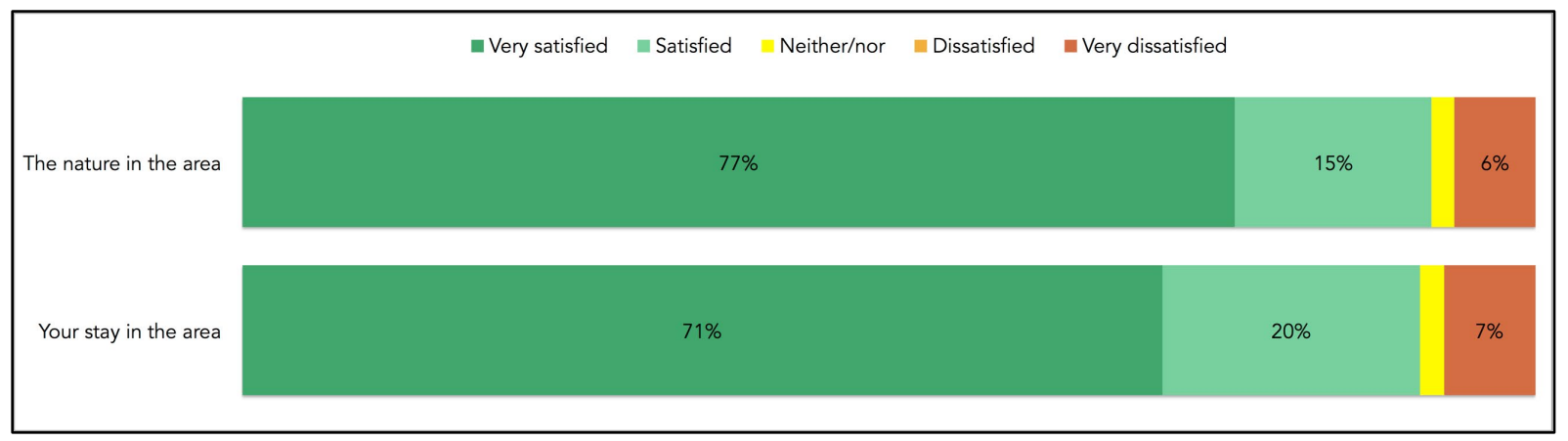

Figure 2: Visitor satisfaction with the nature and with their stay in Skagafjarđardalir or nearby (Burns \& Haraldsdóttir, 2016).

4.1.3 Attitudes toward hydropower in the area, and management preferences

Because the condition of natural features is central to visitor experiences of natural areas (Tonge \& Moore, 2017, p.770), and satisfaction is a consequence of experience, we aimed to discover how visitor experiences, and thus satisfaction, might change if the condition of 
the natural features was altered. In natural areas the demand for services is usually secondary to the condition of the natural area in terms of overall visitor satisfaction. Consequently, the situation proposed by the development of hydropower; that is, reduced natural features but enhanced services and facilities, such as improved road infrastructure, was less favourably received. For example, one respondent stated: "This is not the nature I'm looking for in Iceland, I have this in Germany". This visitor came to Iceland to escape this type of infrastructure and did not want to experience it as part of their visit, an opinion shared by many others (e.g., "I came to Iceland to get away from those things"). This accords with the literature findings that visitors are more likely than locals to place high value on a perceived unchanged landscape.

One of the potential benefits of a hydroelectric power station in the region would be increased road infrastructure and improvement of existing roads. Very few roads currently exist in the area, and they are mostly gravel tracks that are impassible in winter. However, improving roads was not strongly supported by visitors, of whom $39 \%$ thought improving the roads in the area was undesirable or very undesirable and only $21 \%$ considered road improvement to be desirable or very desirable.

In total, $89 \%$ said that the existence of human-made structures in the area would affect their experience of wilderness. However, further examination showed that the type of structure was important: the presence of mountains huts and trails were far less likely to disrupt wilderness values than radio masts or power plants. The most negatively perceived structures or facilities in the area were power lines (61\%), reservoirs $(60 \%)$, and hydro power plants (59\%) (Figure 3). Three-quarters of respondents (68-77\%) agreed or strongly agreed that any of the three power plant proposals and associated infrastructure would negatively affect their decision to visit the area.

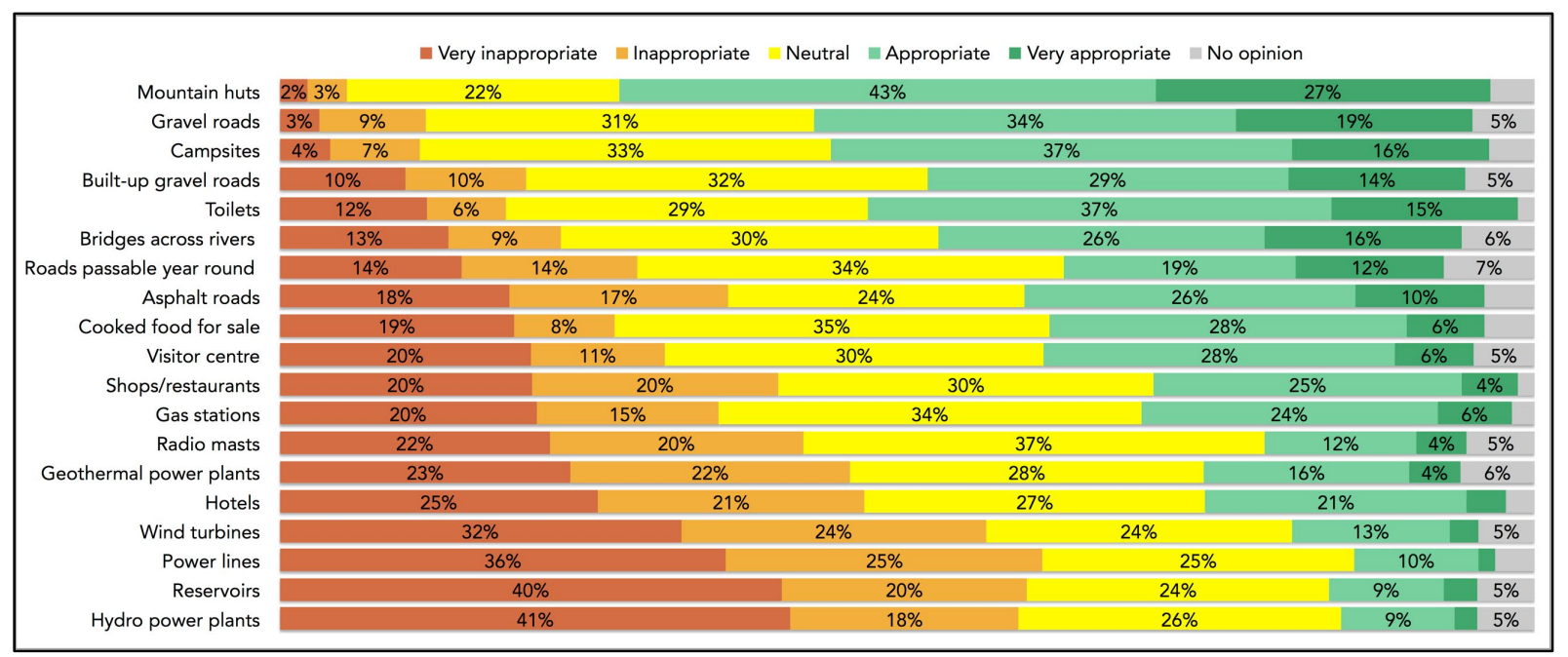

Figure 3: Visitor opinions about structures and facilities in Skagafjarđardalir (Burns \& Haraldsdóttir, 2016).

Results from the questionnaire demonstrate that visitors from a wide range of ages and originating in a wide range of countries (Table 1), seek recreation in this region and are satisfied with their experience of it. Perception of wilderness or unspoiled nature is critical to the value of this area as a destination for visitors and the presence of structures, even those that are unseen but known about, distracts from this value. From comments in the 
open-ended sections of the questionnaire, it was apparent that the construction of hydropower facilities may even prevent visitors from coming to the area.

"This would prevent me from coming back to visit and invest in an Iceland holiday"

"Would find another country for a wilderness experience"

\subsection{Interview Data: operator profile and perspectives}

The semantic content analysis of the interview data identified several key themes concerning operator perceptions of the region, attitudes toward land use alternatives and satisfaction with current, and potential, tourism products. The results reported here focus on the key themes dominating the interviews and identify both similarities and contrasts in the views of the operators.

\subsubsection{Tourism operator profile}

A wide range of business types, which varied in their distance from the potential hydropower sites, were represented in the 20 interviews. While some were operators for just one tourism product, such as a museum or horse shows, others were multi-facted businesses combining, for example, horse riding tours with accommodation. Visitor activities varied according to the type of business, but the activities in the area that would be most effected by the proposed power plants (the Austurdalur valley, the confluence of the two glacial rivers, and the area in the highland above Skagafjarđardalir where the reservoir would be located) were expected to be rafting, horse riding, and hiking. The businesses vary considerably in size, ranging from approximately 50 to 7000 visitors per annum (as estimated by the individual business owners). The origin of visitors at each business also varies. Some tourism operators said their guests were mostly Icelanders, while others said their guests were $99 \%$ non-Icelanders. Some reported a 50/50 mix. This demonstrates that the area is a destination for both local and international visitors, as also evident from the questionniare results where $18 \%$ of respondents identified as Icelandic. Consistent across all operators was the reporting of a noticable growth in visitor numbers in recent years.

Several of the operators described their visitors as "adventure tourists" looking for exhilaration and excitment in their recreational experience (Weber, 2001). This is particularly true of the visitors who take part in rafting or horse riding activities in the area. Operators running hotels or managing tourism agencies were more likely to describe their visitors as "mixed" - both in terms of their perceived type and the recreational activites in which they chose to engage. However, common to most visitors, according to the tourism operators, was an interest in nature and thus they could also be classified as "nature tourists" (Mehmetoglu, 2005).

The places visited in the region also varied according to the type and location of each business. Businesses located closer to the proposed reservoirs and power station sites, and those accomodating visitors going to or coming from the highlands above Skagafjörður, were more likely to report visitation to the valleys as a primary experience desired by their guests. These are most often specialised rafting, horse riding and/or hiking tours. Businesses located further from the hydropower sites, and less specialised businesses such as accommodation services, also mentioned museums, hot springs and other well known tourist attractions in the broader Skagafjörður region as popular places for their guests to visit. 


\subsubsection{Operator perceptions of the area: opinions on land use and satisfaction}

Operators considered Skagafjarðardalir, expecially Austurdalur (the east valley), and the highland above it to be special. When asked why, the reasons most frequently stated included: the rivers, quietness and peacefullness, nature and vegetation, and access to the highlands. This was common to most businesses, regardless of their type and distance from the proposed power plant sites, although stronger opinions were marked in the answers of the operators closer to the valleys and the highland.

"The glacier river, it all plays together - it is indescribable part of the valley and the experience of the valley"

".. and Merkigil [part of the canyons] pulls, and just the whole area because it is absolute wonder, the whole area there"

"The valleys vegetation is rich and diverse. The rivers. ..., the weather in the valley is pleasant. And then the valley has of course a rich history"

In the context of potential change to what makes the area special as a tourist attraction, statements indicated operator concern that introduction of hydropower could be negative:

"I just want to keep it as it is ... it [the power plant] will disturb the peace of Austurdalur. It won't be this quietness and peace and this wonder that one aspire there, anymore"

"Fossá [a freshwater river, proposed as part of the reservoir for Skatastiađir power station] and its surroundings is one of the country's greatest natural treasures, at least in North Iceland. It would be a terrific mistake to destroy that"

"The area in the highland where Bugslón [the proposed reservoir in the highland above Skagafjörður] is going to be is very special - the landscape and nature. Birdlife and even grazing for animals. Laugarfell [a tourism destination in the highland above Skagafjarðardalir] is a paradise. The reservoir would change much in this landscape".

The construction of hydropower in the area would increase infrastructure in terms of road networks and thus accessibility to the area. We asked operators their opinions on this aspect in terms of its importance and their satisfaction with the existing facilities. Responses were similar across the operators, with only two strongly supporting increased access to Austurdalur by improving the condition and network of roads. While some said access to Austurdalur could be improved, most of those also acknowledged that the types of tourists visiting the region were satisfied with the existing level of accessibility. Unpaved roads currently permit access for hikers, horse riders and four wheel drivers to the northeast part of the valley past Merkigil farm, and across the canyons just south of Merkigil, to the church at Ábær. South of Ábær there are no roads, and people hike, ride or even cycle from there. Rather than being seen as an obstacle, the poor condition of roads into the valley was stated by some operators as an advantage to maintaining the tourism values of the area, and was seen by visitors as part of the adventure experience they were seeking.

"People that are going to Austurdalur don't neccessary want fine roads to there. It is a special type of tourist"

"It is not desirable to make the valley accessible for all kinds of traffic. Then the attraction that pulls tourists to the valley is gone" 
"It would be great to have better roads into the area, but with the rivers gone or the rafting gone it doesn't really matter, you wouldn't be going there to see the scenery once the dams are there"

"It is not an attraction as soon as you have a better road up there. They [roads] would destroy the attraction"

A road to the highlands through Vesturdalur already exists, and many operators thought that road should be improved to increase access to the central highlands for smaller cars, and therefore more variable types of visitors. Thus, there was support from some operators to upgrade and maintain existing roads through Vesturdalur but not to "open up" unlimited access to Austurdalur.

Infrastructure is about far more than roads, and discussions about infrastructure with operators also identified a perceived need for more accommodation and toilet facilities, bridges and signs in the area. However, they also recognised that the opinions of their visitors might differ. When asked what infrastructure visitors wanted, operators replied:

"Hikers, horse riders and nature tourists want to have it simple"

"The tourists that go to Austurdalur want untouched nature and simple infrastructure"

"A big part of the experience from the valley (Austurdalur] is the simple infrastructure there and the (still) unspoilt nature"

These interview statements demonstrate that the operators have clear visions for the type of infrastructure that would be good for their business but at the same time consider that most visitors would be happier without increasing infrastructure in the area. Most operators, like visitors, are satisfied with their experience of the area as it currently is.

4.2.3 Operator attitudes towards hydropower, and land use management preferences

When asked about their opinion of the power stations, four of the 20 operators interviewed were in favour of hydropower stations and 16 were against. The strength of these convictions varied; for example, from those "completely against it" to those who said they were "not really against them at all, it's just a question of whether we need them". The perception of need emerged as a frequently mentioned theme. If establishment of the power stations could be proven to fulfill a need in the local community, then opinion toward them was more likely to be positive. However, the perceived need for more electricity was often associated with foreign businesses, such as the proposed alumina smelter at Hafursstaðir in Skagabyggð (Elliott, 2015), and this contributed to the negtive opinion held by most interviewees.

The perceived impact of the power stations in Skagafjarðardalir on individual business depended largely on how closely the business was aligned with the region in which the stations and reservior would be built, as well as the operators opinion of the power stations. The rafting companies and operators who took tours into Austurdalur and Vesturdalur anticipated the most serious impacts:

"That will kill everything"

"It will ruin everything we have build up here for 27 years" 
Others recognised an indirect impact, even if their own business was not directly effected:

"Yes, both directly as we get guests from the river rafting businesses - and indirectly"

"It would definitely have a high impact on my business even though I'm not operating directly on these two rivers ... it should have an impact on, well, on most people in tourism because people who come rafting tend to buy something else as well, they stay in a hotel or a guesthouse or go horseback riding the day after, or eat at a restaurant or whatever"

"No direct effect. BUT indirect as it all hangs together. All tourism services in the area are dependent on each other"

"Would affect the image of Skagafjörður in a negative way"

Discussing why and how the power stations would effect their business, comments ranged from some foreseeing complete destruction and their business having to close, to the less severe need to change the way they operate.

"These rivers are the biggest attraction for the valleys ... The powerlines will destroy our business completely ... The lines will destroy our riding possibilities, or damage it endlessly"

"I think we are destroying one of the best pearls that we have here in that area. Because there are so many people depending on that place ... I would have one attraction less, and it is the main one"

Most interviewees thought the presence of the power stations would have a negative effect on future tourism development. A lot of these concerns were based around the perception that the stations would destroy the natural environment, thus remove a key attraction for visitors and cause suffering for operators reliant on the area and the river as a resource.

"Skagafjörður is privileged by having the best rafting river in the country. If it is destroyed it will most certainly affect tourism in the area"

"The image of Skagafjörður as tourism destination will be damaged"

"Need to change marketing. You would be riding alongside a dam basically, which doesn't have the same attraction ... it will effect tourism in the area in a big way. ... the thing about North-West Iceland is that it's quite untouched, and it's rural ... but accessible at the same time. ... This thing will just ruin that idea ... It is said to be the best rafting river in Europe, and it's something that you shouldn't sacrifice for extra power ..., because this is something that's unique"

Less negative opinions were expressed by the four operators in favour of the power stations who thought tourism was flexible enough to find new attractions.

"Tourism will adjust to a different situation"

"The nature of Austurdalur as such will not be affected, just the river. As a freshwater river it will be more beautiful"

"I think it is not so bad for tourism"

While a couple of operators mentioned a possible positive impact in the form of better roads, only one operator, whose business is located the furthest from the proposal sites, did not anticipate any negative direct or indirect impacts. 
Without the power stations, most operators saw increased potential for tourism, both in Skagafjarðardalir and in the Skagafjörður area as a whole. For Skagafjarđardalir, increased potential was particularly linked to expanding existing attractions of rafting, hiking and horse back riding. For Skagafjörður, key attractions expected to influence tourism increases were natural resources, diverse recreational oportunities, and the rural surroundings and culture.

When asked which future they preferred, six of the 20 interviewed said they preferred a future without the power stations. One was unwilling to answer, one was uncertain, one said it did not matter, and one said a power plant would have a positive impact on tourism in Skagafjörður as a whole. The remaining ten did not answer the question directly but their responses to this and other questions suggest they would prefer a future without (see quotes above).

Those who prefered a future without the power stations said they felt this way because:

"From a business perspective it kills everything. Dams are a symbol of everything that is bad for a river environment"

"Nature tourism is the future for Icelandic tourism"

"For the sake of the valley - the rivers, nature - everything"

"It is about how we define our region [as residents as well as a tourism destination]"

When asked about the future of the area and tourism development, most respondents were very positive and saw a potential for both growth and diversity while avoiding the overcrowding issues already apparent in the south of Iceland.

"Would like to see slow travel develop - people stay more nights and do more. Should target adventure tourists and develop small businesses"

"It has been a big change in the past few years how many [tourists] say they have come here because of the area being so sparsely populated [...] it seems like tourists are coming here because they want to avoid hotels and accommodation without personal contact with their hosts. They have booked their accommodation according to that all around [Iceland] ... They are looking for this certain concept"

All operators agreed tourism and recreational use in the area could increase and that more visitors could be catered for. To achieve this, access to the broader Skagafjörður area, rather than just Austurdalur, needs to be improved. Suggestions were made that this could be achieved through international air transport to the northern part of Iceland, improving existing main roads, and increasing road services during the winter months. These types of changes would benefit local residents as well as visitors. Similarly, more accommodation, and increased type and number of recreational opportunities were also suggested. The strongest theme that emerged however with regards to improving tourism in the area was a consensus that the existing businesses could work together through more coordinated efforts in marketing and packaging tours: "We have everything ... we just need to make it work a little better".

\section{Discussion and Conclusions}


Increased global demand for energy in the world, with tourism development being one of the many reasons for this and, at the same time, decline of wilderness and recreation attracting landscapes due to new power plants and other energy utilizations, pose a significant challenge for many nature-based tourism destinations. Managing natural and cultural resources is complicated and can be a forum for political and public conflicts. Effective planning becomes increasingly important in this context (Sæpórsdóttir \& Ólafsdóttir, 2017), as does the need for integrated landscape management to accommodate diverging stakeholder views on appropriate land use (Plieninger et al., 2018). This applies to multiple contexts of land use, but not least where plans for tourism and power utilization come together.

This final section integrates findings from the questionnaire and interview responses to understand the views and satisfaction of both visitor and local stakeholders with regard to current and future tourism in Skagafjördur. It also summarises the opinions of these two stakeholder groups on the potential impact of hydropower development.

Visitors, regardless of their origin, age or activity undertaken in the region lean toward leaving the landscape undisturbed by hydropower infrastructure, sharing a perceived sense of the area holding value as a pristine and untouched wilderness. Operators, who are also local residents, are more divided in their opinions, often wanting benefits from both tourism and power generation in the region. Some see these activities as co-existing comfortably. Others do not. Operators furthest away from the site of the proposed power plants, and those whose businesses do not directly rely on the area for the experience they offer to visitors, tend to be the least negative about the potential impacts of hydropower.

The majority of visitors are against the development of hydropower in Skagafjarðardalir. They believe that the associated infrastructure would reduce the quality of their experience in the region that they value for perceived notions of it being untouched and undeveloped. If the quality of their experience is reduced, so would their satisfaction with that experience. Tourism is a large income earner for Iceland, who cannot afford to neglect the wishes of both foreign visitors and locals in destinations like Skagafjarđardalir.

The semantic content analysis identified a number of key themes from the narratives of interviewed operators relevant to their attitudes towards hydropower and what it might mean for their business. Like visitors, they considered the potentially affected area to be special. Although some would welcome increased infrastructure, facilities, and access to the area, they recognised that these were not always favored by visitors. All shared an optimism about the future of tourism in the area without the presence of hydropower.

Satisfaction with environmental conditions is an essential contributor to positive visitor experiences in natural areas (Eagles 2002; Imran et al. 2014; Ryan \& Cessford, 2003; Tonge \& Moore, 2007). This study shows that both the visitors and operators were satisfied with their experience of the region and did not want it to change. These findings have important implications for management of tourism in the region and in Iceland more broadly. They demonstrate the importance of understanding the range of stakeholder opinions and experiences to ensure the best outcomes in terms of satisfaction.

Results were used to compile a report for the Icelandic government (Burns \& Haraldsdóttir 2016) that assisted their decision on how best to manage the future of this natural area. Based upon this, and other reports commissioned as part of the larger study for the Master Plan, the Minister of Environment and Natural Recourses proposed a parliamentary 
resolution on the categorization of the power options (Verkefnisstjórn Rammaáætlunar 2016). In this resolution, the proposal for hydropower in the region was rejected and the area re-classified into a Protection Category. Due to political instability at the time and associated repeated short Parliamentary sessions, the proposal was not fully processed by the Parliament and has not yet been voted upon. Nevertheless, the Ministry proposal to not proceed with hydropower in the region, instead declaring it a protected area, ratifies the claim by Sæpórsdóttir and Saarinen $(2015$, p.1) that the tourism industry "has become an important stakeholder in terms of defining the use and management of wilderness areas". Looking to the future, Iceland needs to consider how to sustainably manage tourism in the area, particularly the need for effective planning. Moving to address this across the country, Iceland's first National Planning Strategy 2015-2026 (National Planning Agency, 2015) was recently adopted.

The voice of the visitor to a region is often missing from national and local planning, even when that planning directly effects recreational user's facilities and experiences. There are many possible reasons for this lack of representation, including government officials' access to visitors, who are usually transient and (if not choosing to recreate in their local area) may not be rate payers. However, as Sæpórsdóttir and Ólafsdóttir (2017) remind us, visitors are often not regarded as stakeholders in the planning process. Evidence suggests this should change. As a growing body of literature attests, their opinions and preferences do matter (Hearne \& Salinas, 2002; Mercado \& Lassoie, 2002). This is particularly so in Iceland where the number of foreign tourists annually visiting the country surpasses the total resident population by seven to one (Óladóttir, 2017).

Although limited to tourism business operators and visitors satisfaction and perspectives on land use, this article demonstrates the need for inclusion of a wide range of stakeholders and interest groups in decision making about land use options. Involving a variety of groups is critically important to discover and address coinherent values, interests and conflicts. Further highlighted in this article is the importance of considering what already exists in the location, and using this knowledge to inform decision making on how much development and what type of tourists are desired in the area.

The findings from this study on visitor and local satisfaction with recreation in Skagafjördur provide a beginning for baseline data that can be used for future monitoring in the area. Such a management approach is strongly recommended. Monitoring satisfaction over time is a key for policy and planning of a destination (Bernini \& Cagnone, 2014), and while the immediate threat of hydropower as a competing land use with recreation in the region has been removed, other changes (for example, degradation of the quality of the environment if visitor numbers rise in the area) may still impact stakeholder satisfaction in the future.

\section{References:}

Alegre, J., \& Garau, J. (2010). Tourist satisfaction and dissatisfaction. Annals of Tourism Research, 37, 52-73.

Arinbjarnarson, H. (2016). NI vestra_11apr_laufey. Excel sheet. Personal communication via email 11.4.14.

Askja Energy (2017). The hydro and geothermal history. https://askjaenergy.com/icelandrenewable-energy-sources/hydro-and-geothermal-history. Accessed 5.2.2018. 
Bernini, C. \& Cagnone, S. (2014). Analysing tourist satisfaction at a mature and multiproduct destination. Current Issues in Tourism, 17, 1-20.

Burns, G.L. \& Haraldsdóttir, L. (2016). Potential Effects of Proposed Power Plants on Tourism in Skagafjörđur, Iceland. http://www.ramma.is/media/rannsoknir-f2-

a3/SkagafjordurTourismReport20April2016.pdf. Accessed 5.2.2018.

Eagles, P.F.J. (2014). Research priorities in park tourism, Journal of Sustainable Tourism, 22, 528-549, DOI: 10.1080/09669582.2013.785554.

Eagles, P.F.J. (2002). Trends in park tourism: Economics, finance and management. Journal of Sustainable Tourism, 10, 132-153.

Elliott, A. (2015). Northwest Iceland Signs Contract for New Aluminum Smelter. Iceland Review. On Line. http://icelandreview.com/news/2015/06/14/northwest-iceland-signscontract-new-aluminum-smelter?language=en. Accessed 5.2.2018.

Energy NB Power (2016). Considering the future of Mactaquac: a discussion paper from the utility's perspective. https://www.nbpower.com/media/169868/mtq-discussion-paperen.pdf. Accessed 5.2.2018.

Federal Energy Regulatory Commission (1996). The Cushman Hydroelectric Project (FERC Project No. 460): Environmental Impact Statement. Washington: Office of Hydropower Licencing.

Ferđamálastofa (2012). Handbókin 2012. Akureyri: Ferđamálastofa.

Frantál, B., \& Kunc, J. (2011). Wind turbines in tourism landscapes. Annals of Tourism Research, 38, 499-519. DOI: 10.1016/j.annals.2010.10.007.

Gíslason, S. (ed.) (2016). Lokaskýrsla verkefnisstjórnar 3. áfanga verndar-og orkunýtingaráætlunar 2013-2017. Reykjavík: Verkefnisstjórn 3. áfanga verndar- og orkunýtingaráætlunar og Umhverfis- og auðlindaráðuneyti.

Haukeland, J.V. (2011). Tourism stakeholders' perceptions of national park management in Norway. Journal of Sustainable Tourism, 19, 133-153, DOI: 10.1080/09669582.2010.517389

Hearne, R.R. \& Salinas, Z. M. (2002). The use of choice experiments in the analysis of tourist preferences for ecotourism development in Costa Rica. Journal of Environmental Management, 65, 153-163.

Hornback, K., \& Eagles, P.F.J. (1999). Guidelines for Public Use Measurement and Reporting at Parks and Protected Areas. Gland, Switzerland and Cambridge, UK: IUCN.

HydroElectric Corporation (2017). Waddamana Power Station Heritage Site. https://www.hydro.com.au/things-to-do/waddamana-heritage-site. Accessed 5.02.2018.

Imran, S., Khorshed, A. \& Beaumont, N. (2014). Environmental orientations and environmental behaviour: Perceptions of protected area tourism stakeholders. Tourism Management, 40, 290-299.

Karlsdóttir, U.B. (2010). Par sem fossarnir falla. Náttúrusýn og nýting fallvatna á Íslandi 1900-2008. Reykjavík: Hið íslenska bókmenntafélag, (Chapter 7).

Keirnan, K. (2017). The Original Lake Pedder, Southwest Tasmania: Origin, Age and Evolution of an Australian Nature Conservation Icon. Geoheritage, p1-19.

https://doi.org/10.1007/s12371-017-0276-6. 
Kvale, S. \& Brinkmann, S. (2009). Interviews. Learning the craft of Qualitative Research Interviewing ( $2^{\text {nd }}$ ed.). Thousand Oaks: Sage Publications, Inc.

Lee, J., Graefe, A.R., \& Burns, R.C. (2004). Service quality, satisfaction, and behavioural intention among forest visitors. Journal of Travel \& Tourism Marketing, 17(1), 73-82. doi:10.1300/J073v17n01_05.

Mehmetoglu, M. (2005). A case study of nature-based tourists: Specialists versus generalists. Journal of Vocation Marketing, 11, 357-369.

Mercado, L. \& Lassoie, J. (2002). Assessing tourists' preferences for recreational and environmental management programs central to the sustainable development of a tourism area in the Dominican Republic. Environment, Development and Sustainability, 4, 253-278.

Mohamad, Z., Ramli, N., Muslim, A. \& Hii, Y.S. (2017). Tourism Operator Sustainability Predictive Model in Marine Park. International Review of Management and Marketing, 7. 2. 161-165.

Moore, S.A., Rodger, K. \& Taplin, R. (2015) Moving beyond visitor satisfaction to loyalty in nature-based tourism: a review and research agenda. Current Issues in Tourism, 18 (7). pp. 667-683. http://dx.doi.org/10.1080/13683500.2013.790346

Morgunblađið (1975). Rannsóknir í Skagafirđi: Villinganesvirkjun dygđi án orkufreks iðnađar nyrðra. Morgunblađiđ, 23 August 1975. p13.

Moisey, R.N. \& McCool, S.F. (2001). Sustainable tourism in the 21st century: lessons from the past, challenges to address. In S. F. McCool \& R. N. Moisey (Eds.), Tourism, recreation and sustainability: linking culture and the environment (pp. 283-291). Wallingford: $C A B$ International.

National Planning Agency (2015). Landsskipulagsstefna 2015-2026. Tillaga til umhverfis- og auðlindaráđherra (The National planning strategy 2015-2025. Proposal to the minister for the Environment and Natural Resources). http://www.landsskipulag.is/umlandsskipulagsstefnu/frettir/nr/1130. Accessed 5.2.2018.

Neuendorf, K. (2017). The Content Analysis Guidebook. London: Sage Publications Ltd.

Newsome, D., Moore, S. \& Dowling, R. (2002). Natural Area Tourism: Ecology, impacts, and management. Clevedon: Channel View Publications.

Newsome, D., Moore, S.A., \& Dowling, R. (2013). Natural Area Tourism: Ecology, impacts and management. $2^{\text {nd }}$ edition. Clevedon: Channel View Publications.

Óladóttir, O.P. (2017). Ferđapjónusta á Íslandi í tölum apríl 2017. Reykjavík: Ferđamálastofa.

Ólafsson, K. (ed.) (2006). Áfangaskýrsla 1 - stöđulýsing og upphaf framkvæmda á

Austurlandi (Rannsóknarrit nr. 3). Akureyri: Byggđarannsóknarstofnun Íslands.

Pálsson, P. (eds.) (2017). Sveitarfélagið Skagafjörđur. Stefnumótun í ferđapjónustu, 20162020, 5-11. Sauðárkrókur: Sveitarfélagið Skagafjörđur og Thorp ehf

Pearce, J. \& Dowling, R. (2018). Monitoring the quality of the visitor experience: An evolutionary journey. Accepted for publication in the Journal of Outdoor Recreation and Tourism, November 2017. This Issue.

Plieninger, T., Áargarð av Rana, H., Fagerholm, N., Fossaberg Ellinsgaard, G., Magnussen, E., Raymond, C.M., Olafsson, A.S. \& Verbrugge, L.N.H. (2018). Identifying and assessing the 
potential for conflict between landscape values and development preferences on the Faroe Islands. Global Environmental Change, 52, 162-180.

Pybus, C. \& Flanagan. R. (eds) (1990). The Rest of the World is Watching. Sydney: Pan Macmillian.

Rodger, K., Moore, S.A., \& Taplin, R. (2012). Visitor satisfaction, loyalty and protected areas: A review and the future. Report prepared for the WA Department of Environment and Conservation, Parks Victoria and the Parks Forum. Murdoch, WA: Technical Report. School of Environmental Science, Murdoch University.

Rodriguez, J-F. (2012). Hydropower landscapes and tourism development in the Pyrenees. Revue de Géographie Alpine / Journal of Alpine Research [Online], 100-2. URL: http://rga.revues.org/1819; DO: 10.4000/rga.1819

Rögnvaldsson, G. (2000). Áhrif væntanlegrar Villinganesvirkjunar á ferđapjónustu í sunnanverđum Skagafirđi. Hólum í Hjaltadal: Hólaskóli - Ferđamálabraut.

Ryan, C., \& Cessford, G. (2003). Developing a visitor satisfaction monitoring methodology: Quality gaps, crowding and some results. Current Issues in Tourism, 6, 457-507.

Sæpórsdóttir, A.D. \& Hall, C. M. (2018). Floating away: the impact of hydroelectric power stations on tourist's experience in Iceland. Sustainability, 10. DOI:10.3390/su10072315.

Sæpórsdóttir, A.D. \& Ólafsdóttir, R. (2017). Planning the wild: In times of tourist invasion. Journal of Tourism and Research Hospitality, 6, 1-7.

Sæpórsdóttir, A.D., Ólafsdóttir, R. \& Smith, D. (2018). Turbulent times: tourists' attitudes towards wind turbines in the Southern Highlands in Iceland. International Journal of Sustainable Energy, 37, 886-901. DOI: 10.1080/14786451.2017.1388236

Sæbórsdóttir, A.D. \& Ólafsson, R. (2010). Nature tourism assessment in the Icelandic Master Plan for geothermal and hydropower development. Part I: rapid evaluation of nature tourism resources. Journal of Heritage Tourism, 5, 311-331.

Sæpórsdóttir, A.D. \& Saarinen, J. (2015). Changing ideas about natural resources: tourists' perspectives on the wilderness and power production in Iceland. Scandinavian Journal of Hospitality and Tourism, 16, 404-421. DOI: 10.1080/15022250.2015.1108866

Schweinsberg, S., Wearing, S. \& Wearing, M. (2015). Transforming Nature's Value - Cultural Change Comes from Below: Rural Communities, the 'Othered' and Host Capacity Building. In Y. Reisinger (ed), Transformational Tourism: Host Perspectives. CAB International. Pp 102113.

Tonge, J. \& Moore, S.A. (2007). Importance-satisfaction analysis for marine-park hinterlands: A Western Australian case study. Tourism Management, 28, 768-776.

Verkefnisstjórn Rammaáætlunar (2016). Ráđherra leggur fram pingsályktun um rammaáætlun. (The Steering Committee for the Master Plan (2016). The Minister proposes a parliamentary resolution on the Master Plan). http://www.ramma.is/frettasafn/radherraleggur-fram-thingsalyktun-um-rammaaaetlun. Accessed 1.9.2018.

Wade, D.J., \& Eagles, P.F.J. (2003). The use of importance-performance analysis and market segmentation for tourism management in parks and protected areas: An application to 
Tanzania's National Parks. Journal of Ecotourism, 3, 196-212.

doi:10.1080/14724040308668144

Weber, K. (2001). Outdoor adventure tourism: A review of research approaches. Annals of Tourism Research, 28, 360-377.

Williams, P. \& Soutar, G. (2007). Close to the "edge": critical issues for adventure tourism operators. Asia Pacific Journal of Tourism Research, 10, 3, 247-261.

\section{Vitae}

Georgette Leah Burns holds a PhD in Tourism from Murdoch University and is a foundation member of the Environmental Futures Research Institute at Griffith University. She is a Senior Lecturer in the School of Environment and Science at Griffith University, and previously held positions as Head of the Tourism Department at Hólar University College and Head of Tourism Research at the Icelandic Seal Centre. As an environmental anthropologist, Leah's research on wildlife tourism interactions spans topics such as ethics, coexistence, sustainability, resilience, interpretation and management.

Laufey Haraldsdóttir holds a Cand. Med. Vet. in Veterinary Medicine from the Norwegian University of Life Sciences, and a MA in ethnology from the University of Iceland. She is an assistant professor, and current Head of the Department of Rural Tourism at Hólar University College. Laufey's research is on food, culture and rural tourism and spans topics such as place and placemaking, locality, identity, sustainability and New Nordic Cuisine.

\section{Acknowledgements}

We would like to thank Egill Björn Thorstensen for his assistance with collection and collation of data for this project. His dedication to approaching visitors in camp sites and hotels, and even road side service stations, ensured we had a sufficient number of questionnaire respondents to make the study worthwhile.

We are also very grateful to all the respondents in this project who willingly gave up their time to assist us. Most particularly, thanks to the interviewees who generously accepted us into their homes and businesses asking probing questions and accepting their hospitality.

This work was made possible by funding from the Icelandic Ministry for the Environment and Natural Resources, to whom we are also most grateful. 